[Review]

\title{
The Effectiveness of Specific Risk Mitigation Techniques Used in the Production and Handling of Manufactured Nanomaterials: A Systematic Review
}

\author{
Toshihiko Myojo $^{1 *}$, Tomohisa NAgAta ${ }^{2}$ and Jos VerbeEK ${ }^{3}$ \\ ${ }^{1}$ Department of Environmental Health Engineering, Institute of Industrial and Ecological Sciences, University of Oc- \\ cupational and Environmental Health, Japan. Yahatanishi-ku, Kitakyushu 807-8555, Japan \\ 2 Department of Occupational Health Practice and Management, Institute of Industrial and Ecological Sciences, Uni- \\ versity of Occupational and Environmental Health, Japan. Yahatanishi-ku, Kitakyushu 807-8555, Japan \\ ${ }^{3}$ Finnish Institute of Occupational Health, Cochrane Work Review Group, PO Box 310, 70101 Kuopio, Finland
}

\begin{abstract}
Many kinds of manufactured nanomaterials (MNMs) have been developed and used as basic materials of industrial products, and they may pose health risks for workers in not only developed countries but also in developing countries. Few studies have looked at the evidence for effects of controls that mitigate the risk of exposure to MNMs. Therefore, we systematically searched the literature from the year 2000 to 2015 . We included studies that compared the use of an exposure control to the situation without such a technique and those that measured the exposure to MNMs as the outcome. In order to evaluate the effectiveness of these controls, we used their "protection factor", defined as the ratio between concentrations without and with the control. We located 1,131 references in PubMed and other lists, and out of these references, 41 studies fulfilled our inclusion criteria. We categorized them as engineering controls such as enclosure, local exhaust ventilation or process automation, and as personal protective equipment (PPE). For enclosure systems we found a protection factor beyond 100. For other engineering controls, the better controls scored 10 to 20, but many cases of local exhaust ventilation had a protection factor of less than 10 and some cases even increased exposure. PPE such as N95 or equivalent filtering respirators had a protection factor of approximately 10 tested with nano-sized aerosols. We conclude that there is low quality evidence that specific engineering controls can reduce exposure to MNMs but that enclosure is considerably more effective. For respiratory protection the evidence is of very low quality due to the lack of field studies. This information can be used to decide about controls when exposure to MNMs exceeds proposed occupational exposure limits or when no toxicological information is available for a MNM.
\end{abstract}

Keywords : manufactured nanomaterials, systematic review, engineering control, respirator, process automation.

(Received August 2, 2017, accepted August 22, 2017)

\section{Introduction}

"Nanomaterials" are materials of which a single unit is between 1 and $100 \mathrm{~nm}$ in size; in other words, nanoscale. According to ISO/TS (International Orga- nization for Standardization/Technical Specification) 80004-2: 2015, a single unit is called a nano-object, and is defined as a material with one, two or three external dimensions in the size range of nanoscale. Subcategories of the nano-object are nanoplate, nanofiber

*Corresponding Author: Toshihiko Myojo, PhD, Department of Environmental Health Engineering, Institute of Industrial and Ecological Sciences, University of Occupational and Environmental Health, Japan. Yahatanishi-ku, Kitakyushu 807-8555, Japan, Tel: +81-93-691-7459, Fax: +81-93-602-

7406, Email: tmyojo@med.uoeh-u.ac.jp 
and nanoparticle, based on the nanoscale dimensions [1]. This definition applies to intentionally produced nanomaterials as manufactured nanomaterials (MNMs). Among the various nanomaterials, carbon black, fumed silica, and titanium dioxide are currently mass-produced and used commonly, while the newer carbon nanomaterial fullerene and the fibrous nanomaterials single- and multi-walled carbon nanotubes (SWCNTs and MWCNTs, respectively) are becoming common, with applications and production expanding from the laboratory to industrial levels. Nanomaterials often have unique optical, electronic, or mechanical properties, but in addition to offering the intended benefits, they may also pose unforeseen adverse environmental, health, and social risks.

Information about the health effects of MNMs has been accumulated over the last decade and some MNMs pose similar health risks as the bulk material. For other MNMs it is clear that the MNM-form and size pose new health risks compared to the bulk material, such as with CNTs. For again other MNMs there is not enough information to be able to assess the health risks. Given that exposure beyond the proposed occupational exposure limits has been reported to occur frequently, there is a need for measures to control exposure [2,3].

The hierarchy of control measures stipulates that control measures are taken in the following order of priority: 1) Eliminate the hazard, 2) Substitute the hazardous material with a less harmful agent, 3) Change the process, 4) Apply engineering controls, 5) Consider administrative controls, and 6) Use personal protective equipment (PPE). In the case of MNMs, it would be difficult to apply 1) and 2) because MNMs are used because of the specific properties of the material. Therefore the first control measure -3 ) to change the process - should always be considered first. However, any combination of the above control measures will potentially minimize the risk.

The World Health Organization (WHO) started to develop guidelines for protecting workers from potential risks of MNMs in 2010. In the process of developing the guidelines, 10 questions were listed that should lead to recommendations, and the WHO Global Network of Collaborating Centers in Occupational Health offered to systematically review the evidence from published research. Some of these reviews have been published already $[2,3]$. In our review, we tried to find information to answer the question "What risk mitigation techniques should be used for specific nanomaterials or groups of nanomaterials and specific exposure situations, and what are the criteria for evaluating the effectiveness of the controls?"

\section{Methods}

\section{PICO approach}

We framed an answerable question according to the PICO acronym (P for Participants, I for Intervention, $\mathrm{C}$ for Comparators, and $\mathrm{O}$ for Outcomes) $[4,5]$ and reviewed controlled field and experimental studies on exposure mitigation for workers. We included any controlled study that was either a before-after comparison in which the level of exposure was compared before and after installing controls, or a controlled before-after comparison in which the change in exposure in the intervention group was compared to the change in exposure in the control group.

Participants (P) were workers exposed to or workplaces with exposure to MNMs or products containing MNMs across all the stages of the life cycle (synthesis, manufacture, downstream use, and disposal and recycling). Exposure should include a description of the size or size-distribution of the MNMs and a description of the measurement instruments for the aerosolized MNMs. Exposure to an MNM should fall within the ISO definition: "nanomaterials within the nanotechnology industry as a material with any external dimension in the nanoscale or having internal or surface structure in the nanoscale, with nanoscale defined as the size range from approximately $1 \mathrm{~nm}$ to $100 \mathrm{~nm}$ " [1].

Studies were included if they evaluated one of the three following intervention categories (I): 1. Any type of ventilation or enclosure system in workplaces that affects air flow velocity or aerosol concentration; 2. Any type of personal protective equipment, including respirators, for workers that has filtration performance against nano-size particles or prevents leakage through structural gaps in the PPE; 3. Any type of management of the work environment using rules for work practices or application and maintenance, such as automation or dustiness controls. 
Comparators $(\mathrm{C})$ were no mitigation techniques.

Outcomes (O) were the level of exposure to the nanomaterials as aerosolized MNMs or general nanosize aerosols.

Several scales of effectiveness of mitigation against nanomaterial exposure are potentially available. In this review, we used the protection factor as the measure of effectiveness of a control which was defined as exposure concentrations without and with control for ventilation or other engineering control techniques $\left(\mathrm{PF}_{\text {eng }}=\right.$ $\mathrm{C}_{\text {without }} / \mathrm{C}_{\text {with }}$ ), and $\mathrm{PF}_{\text {res }}$ means the $\mathrm{PF}\left(=\mathrm{C}_{\text {out }} / \mathrm{C}_{\text {in }} ;\right.$ concentrations outside of and inside a respirator) for respirators. $\mathrm{PF}>1$ means that the exposure is reduced, $\mathrm{PF}$ $=1$ means no effect on exposure, and $\mathrm{PF}<1$ means an increase of exposure with the control. The value of PF will be compared to the ratio of real exposure level and occupational exposure limit of specific MNMs, which have been reviewed in previous reports $[2,3]$.

\section{Sources of information and research strategy}

To develop a comprehensive list of potentially relevant studies, PubMed was searched for literature from the year 2000 to the end of 2015 . The search strategy and the terms are listed in Table 1.

Study selection

Two reviewers independently checked if any titles and abstracts that came up in the search did not fulfill one or more of the inclusion criteria and thus could be excluded. The remaining articles resulting from this selection process were assessed again by two reviewers based on the full text of the articles to see which articles fulfilled all the inclusion criteria. If there was a disagreement about whether a paper should be included or not, consensus was reached by discussion. Articles that described the same study were included only once, referencing that one study. This resulted in the list of included studies. Studies that did not refer to occupational settings or exposure situations and studies on MNMs that did not fall under the ISO definition were excluded in the selection process.

\section{Data collection process}

Each risk mitigation technique in the extracted papers was categorized into a specific control category and a given nanomaterial. A single study could describe several exposure situations and provide a series of outcomes. For example, an investigation conducted on one nanomaterial with three different control measures, or three brands of respirator, or three production systems performed in the same field, was counted as three cases. Globally, the following data were extracted: references, characteristics of the participants and interventions, outcomes, and authors' conclusions.

\section{Table 1. List of terms for search}

("nanostructures" [MeSH Terms] OR "nanostructures" [All Fields] OR "nanomaterials" [All Fields] OR "nanoparticles" [MeSH Terms] OR "nanoparticles" [All Fields] OR "nanoparticle" [All Fields] OR "nanofibers" [MeSH Terms] OR "nanofibers" [All Fields] OR "nanofiber" [All Fields])

AND

(exhaust [All Fields] OR “ventilation*” [MeSH Terms] OR “ventilation*” [All Fields] OR “respiration*” [MeSH Terms] OR "respiration*" [All Fields]

OR

“mask*" [All Fields] OR ("ventilator*” [All Fields] AND “mechanical” [All Fields]) OR "mechanical ventilator*” [All Fields] OR "respirator*” [All Fields] OR "personal protective equipment*” [All Fields] OR "PPE*” [All Fields]

OR

"risk reduction*" [All Fields] OR countermeasure [All Fields] OR countermeasures [All Fields] OR countermeasured [All Fields] OR countermeasurements [All Fields]

OR

(automation [All Fields] OR automationof [All Fields] OR automations [All Fields] OR automatization [All Fields] OR automatizational [All Fields]) AND exposure [All Fields]

OR

(wetting [All Fields] OR wettings [All Fields] OR dewetting [All Fields] OR wettingen [All Fields] OR wettinger [All Fields] OR wettingfeld [All Fields] OR wettinglike [All Fields] OR dustiness [All Fields]) AND exposure [All Fields]) 
Assessment of risk of bias and other methodological quality items in included studies

We assessed the risk of bias in the included studies by using the following three items: 1 . Intervention and control condition were comparable with regards to the type of work and working conditions based on the pairs of descriptions with and without intervention; 2. Measurement of the MNM was done with state of the art instruments or methods; 3 . The intervention was fully implemented and technically according to the state of the art.

Each item (RB1, RB2, RB3) was scored with yes/ no/can't judge and coded as $1 /-1 / 0$. Primary data which were presented originally in the paper by the authors was 'yes (1)', and secondary data which were cited from previous papers by the authors was 'no $(-1)$ '. Thus, a score of plus 3 indicates a low risk of bias and a score of -3 a high risk of bias. In addition, we used the following ten items to indicate the methodological quality of each study: precise specification of application area task and workplace; validation in field study; quality assessment; quality management; standard operating procedure; hazard data; exposure data; data on efficacy of controls; data on bias and confounding; and evidence of physico-chemical characterization of MNMs. The score of each item is from -2 to 2 , and the total of the scores is from -20 to 20 .

\section{Synthesis of study outcomes}

Estimation of the protection factors in the situations was based on the values in the papers, such as concentration of airborne MNMs. We narratively described the protection factors for each intervention for each category and did not try to synthesize the findings in a meta-analysis because the exposure data did not lend itself to such an analysis.

\section{Overall assessment of the quality of the evidence}

We used a modified GRADE (Grading of Recommendations, Assessment, Development and Evaluations) approach to assess the overall quality of the evidence per category of controls [3]. We started with low quality if the evidence was from observational studies and with high quality if the evidence was from randomized studies. We downgraded the evidence by one level if one of the following criteria were met:
Most studies with high risk of bias, No direct answer to our PICO question; for example no field studies, Inconsistent outcomes in studies, Imprecision of the study results, Publication bias present.

\section{Results}

\section{Results of the search}

A total of 1,131 references were identified through the search in the PubMed database. 1,066 records were excluded based on the title. Abstracts of 65 records were checked full-text and of these 27 were excluded. This led to 38 papers that fulfilled our inclusion criteria. We excluded eight studies on risk management and one description of a safety data sheet because the authors did not include any primary study data. Members of the guideline development group also provided lists of related papers for this review using a library for efficacy of control measures named ECEL (Exposure Control Efficacy Library, associated with the Advanced REACH tool) [6]. Most of the references were duplicates, but 12 papers, which covered engineering controls (6) and PPE (6), were added. This resulted in a final list of 41 studies. A flow diagram of the study selection process is shown in Fig. 1.

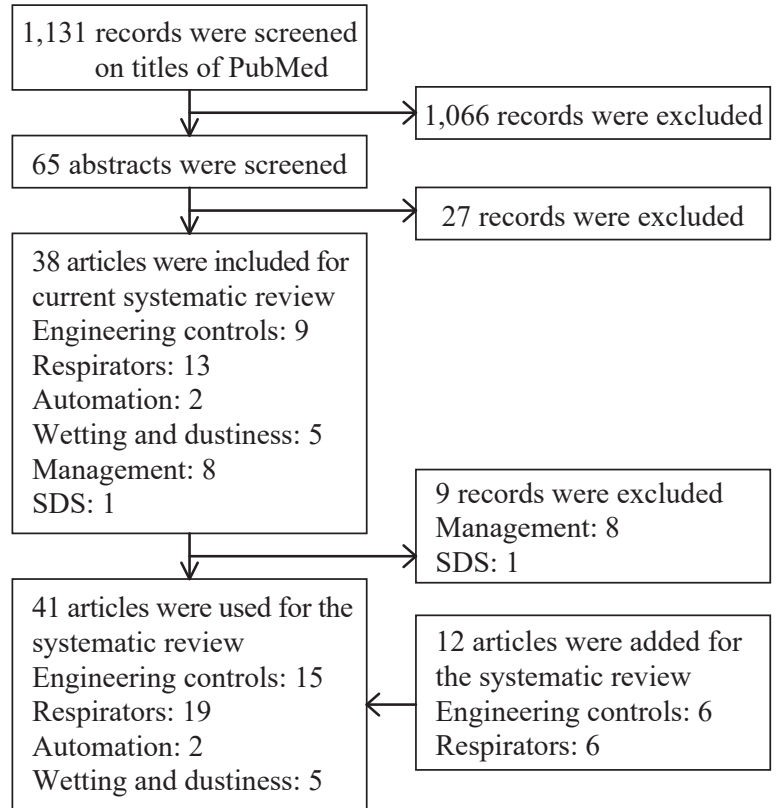

Fig. 1. Flow chart depicting the procedure for selection of relevant papers. SDS: Safety data sheets. 
Table 2. List of extracted and reviewed papers and the quality of evidence and risk of bias

\begin{tabular}{|c|c|c|c|c|c|c|c|c|}
\hline Ref. no. & category & authors & year & quality & $\mathrm{RB} 1$ & RB 2 & RB 3 & RB total \\
\hline 7 & Engineering control & Dunn KH et al & 2014 & 8 & 1 & 1 & 1 & 3 \\
\hline 8 & Engineering control & Heitbrink WA et al & 2015 & 14 & 1 & 1 & 1 & 3 \\
\hline 9 & Engineering control & Lee JH et al & 2013 & 6 & -1 & 1 & 0 & 0 \\
\hline 10 & Engineering control & Cena LG \& Peters TM & 2011 & 10 & 1 & 1 & 1 & 3 \\
\hline 11 & Engineering control & Methner MM & 2010 & 12 & 1 & 1 & 1 & 3 \\
\hline 12 & Engineering control & Hämeri $\mathrm{K}$ et al & 2009 & 6 & 1 & 1 & 1 & 3 \\
\hline 13 & Engineering control & Conti JA et al & 2008 & 11 & -1 & 0 & -1 & -2 \\
\hline 14 & Engineering control & Methner MM & 2008 & 2 & 1 & 1 & 1 & 3 \\
\hline 15 & Engineering control & Tsai SJ et al & 2010 & 15 & 0 & 1 & 0 & 1 \\
\hline 16 & Engineering control & Tsai SJ et al & 2009 & 18 & 1 & 1 & 1 & 3 \\
\hline 17 & Engineering control & Lo LM, et al & 2015 & 14 & 1 & 1 & 1 & 3 \\
\hline 18 & Engineering control & Sahu M \& Biswas P & 2010 & 15 & 1 & 1 & 1 & 3 \\
\hline 19 & Engineering control & Lee MH et al & 2007 & 15 & 0 & 1 & 1 & 2 \\
\hline 20 & Engineering control & Heitbrink WA \& Lo LM & 2015 & 15 & -1 & 1 & 0 & 0 \\
\hline 21 & Engineering control & Han JH et al & 2008 & 12 & 1 & 1 & 0 & 2 \\
\hline 22 & Respirator & He X et al & 2014 & 10 & 1 & 1 & 1 & 3 \\
\hline 23 & Respirator & Brochot $\mathrm{C}$ et al & 2012 & 10 & 1 & 1 & 1 & 3 \\
\hline 24 & Respirator & Rengasamy S et al & 2012 & 6 & 1 & 1 & -1 & 1 \\
\hline 25 & Respirator & Rengasamy S \& Eimer BC & 2012 & 6 & 1 & 1 & 1 & 3 \\
\hline 26 & Respirator & Rengasamy S \& Eimer BC & 2012 & 6 & 1 & 1 & -1 & 1 \\
\hline 27 & Respirator & Reponen $\mathrm{T}$ et al & 2011 & 5 & 1 & 1 & 1 & 3 \\
\hline 28 & Respirator & Rengasamy S et al & 2010 & 6 & 1 & 1 & 1 & 3 \\
\hline 29 & Respirator & Golanski L et al & 2009 & 8 & 1 & 1 & 1 & 3 \\
\hline 30 & Respirator & Rengasamy S et al & 2009 & 8 & 1 & 1 & 1 & 3 \\
\hline 31 & Respirator & Rengasamy S et al & 2008 & 8 & 1 & 1 & 1 & 3 \\
\hline 32 & Respirator & Balazy A et al & 2006 & 10 & 1 & 1 & 1 & 3 \\
\hline 33 & Respirator & Li Y et al & 2006 & -7 & -1 & -1 & -1 & -3 \\
\hline 34 & Respirator & Koivisto AJ et al & 2015 & 14 & 1 & 1 & 1 & 3 \\
\hline 35 & Respirator & Tsai SJ & 2015 & 7 & -1 & 1 & -1 & -1 \\
\hline 36 & Respirator & Rengasamy S \& Eimer BC & 2011 & 9 & 0 & 1 & 0 & 1 \\
\hline 37 & Respirator & Vo E \& Zhuang Z & 2013 & 14 & 1 & 1 & 1 & 3 \\
\hline 38 & Respirator & Vo E et al & 2014 & 14 & 1 & 0 & 0 & 1 \\
\hline 39 & Respirator & Vo E et al & 2015 & 13 & 1 & 1 & 1 & 3 \\
\hline 40 & Respirator & He X et al & 2015 & 13 & 1 & 1 & 1 & 3 \\
\hline 41 & Automation & Koivisto AJ et al & 2012 & 18 & 0 & 1 & 1 & 2 \\
\hline 42 & Automation & Takaya M et al & 2010 & 17 & 1 & 1 & 1 & 3 \\
\hline 43 & Dustiness & Evans DE et al & 2013 & 13 & -1 & 1 & 0 & 0 \\
\hline 44 & Dustiness & O’Shaughnessy PT et al & 2012 & 14 & -1 & 1 & 0 & 0 \\
\hline 45 & Dustiness & Lee JH et al & 2013 & 6 & -1 & 0 & -1 & -2 \\
\hline 46 & Dustiness & Ma-Hock L et al & 2009 & 7 & -1 & 1 & -1 & -1 \\
\hline 47 & Dustiness & Schneider T \& Jensen KA & 2008 & 13 & -1 & 1 & 0 & 0 \\
\hline
\end{tabular}

Quality of evidence; very low ( -20 to -10$)$, low ( -9 to 0$)$, medium (1 to 9$)$, high (10 to 20), RB1, RB2 and RB3 are scores of following items. RB1: intervention and control condition were comparable with regards to the type of work and working conditions based on the pairs of descriptions with and without intervention. RB2: measurement of the MNM was done with state of the art instruments or methods. RB3: the intervention was fully implemented and technically according to the state of the art. RB total is summation of the scores of RB1 to RB3. 


\section{Categorization of risk mitigation techniques}

We found 15 studies on engineering controls including fume cupboards or local exhaust ventilation (LEV) for MNMs. Nineteen papers on PPE, mainly respirators, were extracted. We found two papers on process automation. One paper reported on the replacement of manual handling by packing processes and on an automated system for MWCNTs. We contacted the authors for additional information because the workplace situation was described ambiguously in the paper. Five papers on dustiness were extracted, but there was no paper on research about how to control the dustiness of MNMs actively. There were no papers on dust control by means of wetting MNMs.

The above 41 papers are listed in Table 2 with total scores of GRADE approach and showing risk of bias (RB1, RB2, RB3 and total scores). The reference numbers in this paper are based on this table.

\section{Effects of enclosure and ventilation}

We found 15 studies on engineering controls. One paper on an international survey regarding occupational health and safety programs, engineering controls and PPE, did not contain data on the concentrations of airborne MNMs particles [13] and could not be used for the calculation of PFs. The remaining 14 papers reported on: enclosure systems (down flow clean rooms with ventilated enclosure hood); ventilation (LEV, enclosure type LEV with proper face velocity, process ventilation, biosafety cabinets); specialized ventilation systems (thermal displacement ventilation); and segregation sources (reactor cabinets) [7-12, 14-21].

Based on the scores of the risk of bias in Table 2, we excluded 3 papers because of low scores of the risk of bias, in particular the score of RB1 [9, 15, 20]. The 11 papers reported 27 cases for which we could obtain the $\mathrm{PF}_{\text {eng }}\left[7,8,10^{-12}, 14,16^{-19}, 21\right]$. The $\mathrm{PF}_{\text {eng }}$ were calculated by both mass-based concentrations and number-based concentrations, as shown in Fig. 2.

The $\mathrm{PF}_{\text {eng }}$ of ventilation was less than 10 in the poor cases, and 10 to 20 in the good cases (see Fig. 2). The $\mathrm{PF}_{\text {eng }}>100$ in Fig. 2 means there was no leak, as described in the papers. The recommended face velocity of the enclosure type LEVs ranged from 0.4 to $0.6 \mathrm{~m} / \mathrm{s}$ [7, 16-18].

One paper concluded that a canopy hood for nano-

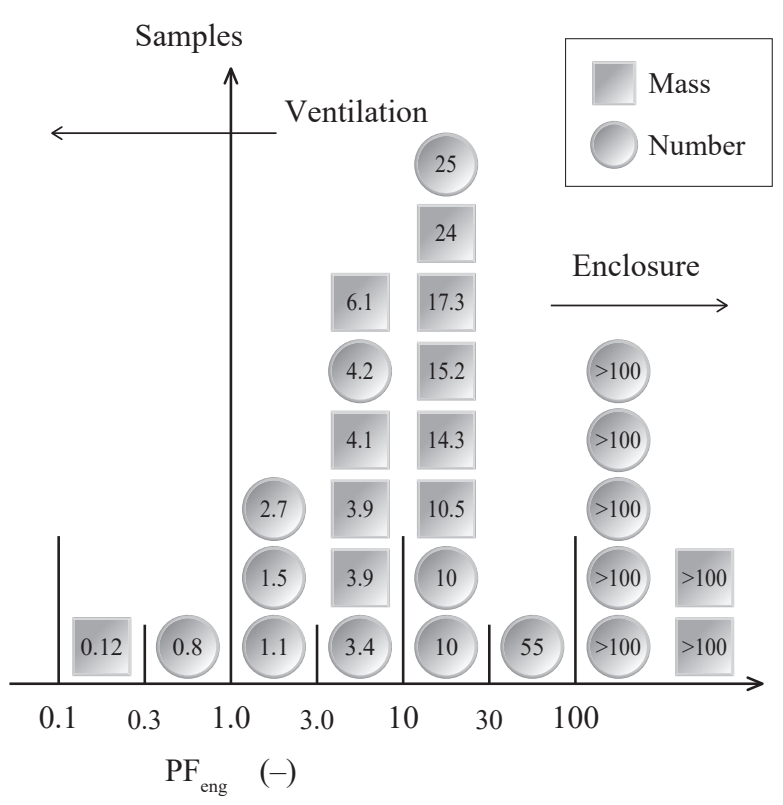

Fig. 2. Protection Factor $\mathbf{P F}_{\text {eng }}$ at ventilation or other engineering control techniques (27 cases in 11 papers). $\mathrm{PF}_{\text {eng }}=\mathrm{C}_{\text {without }} / \mathrm{C}_{\text {with }}$, where $\mathrm{C}_{\text {without }}$ is concentration without mitigation techniques and $\mathrm{C}_{\text {with }}$ is concentration with mitigation techniques. PF $>100$ in the Figure means no leak as described in the papers and in most of the cases, enclosure systems were used. Mass means $\mathrm{PF}_{\text {eng }}$ calculated by mass-based concentrations and Number means $\mathrm{PF}_{\text {eng }}$ calculated numberbased concentrations.

composite cutting led to an increase in exposure $(\mathrm{PF}=$ $0.8)$ [17]. LEVs with low face velocity provided the lowest PF (=0.125) and worsened the situation [10]. The authors concluded that poor performance of the custom hood used in the current study may have been exacerbated by its lack of a front sash, its lack of rear baffles to distribute the airflow, and its low face velocity $(0.2 \mathrm{~m} / \mathrm{s})$.

All studies were observational, the majority had low risk of bias, all results were direct answers to our PICO question, and the results were consistent across studies, but no study included measures of precision and we could not establish publication bias. Because imprecision is difficult to establish for exposure measures, we decided not to downgrade them and rated the evidence as low quality.

\section{Effects of suppression and separation of workers}

This section corresponded to the categories of ' 6 Suppression technique' and '7 Separation worker' by Fransman et al; that is, process automation and dusti- 
ness tests or wetting [6].

We extracted 2 papers covering 5 cases of process automation to obtain the $\mathrm{PF}_{\text {eng. }}$. One paper reported on a $\mathrm{TiO}_{2}$ packing machine operation [41] and the other reported on a comparison between a manual MWCNT packing process and an automated packing machine [42]. Even in the use of an automated packing machine, workers can be exposed to nanomaterials when the packing closure is opened and nanomaterials are poured into a silo. At a nanoTiO ${ }_{2}$ handling facility, a momentary $\mathrm{PF}_{\text {eng }}=0.073$ was reported [41].

The $\mathrm{PF}_{\text {eng }}$ of process automation depended on the sampling method, stationary sampling or workers breathing zone sampling (WBZ), at a MWCNT production facility [42]. Besides mass concentrations, elemental carbon mass (EC) concentrations were also measured as an index of airborne MWCNT. In the breathing zone based on total mass, the $\mathrm{PF}_{\text {eng }}$ was 8.2 ; in the breathing zone based on respirable mass, the $\mathrm{PF}_{\text {eng }}$ was only 4.9; and in the breathing zone based on EC mass, the $\mathrm{PF}_{\text {eng }}$ was 7 . With stationary sampling and based on total mass there was no effect of automation, but based on the $\mathrm{EC}$ mass the $\mathrm{PF}_{\text {eng }}$ was 2.5. The automated packing machine was not covered completely, but the workers did not have to fully attend to the operation of the machine.

We found five papers that measured dustiness [4347]. However, there was no paper that compared changes in the dustiness of nanomaterials, wetting or surface coating of the nanomaterials. However, three papers suggested that nanomaterials had much higher dustiness than pigment grade (submicron size) materials of the same chemical composition and thus could be subject to suppression controls [43, 44, 47].

All studies were observational. For automation, the risk of bias was low and the PICO was directly answered, but there were only two studies with inconsistent results. Therefore we downgraded the evidence by one level to very low quality.

\section{Performance of respirators for nanoparticle aerosols}

Respirators are the final resort in risk mitigation for workers handling MNMs. In the extracted papers, filtering facepiece respirators (FFR) or elastomeric half masks with particulate filters (EHR) were studied, and there was one paper on a loose-fitting powered air pu- rifying respirator in the field use handling of MNMs [34]. The classes of the particulate respirators of the FFRs and EHRs in the papers were N95, N99, N100 and P100 certified by US NIOSH (National Institute of Occupational Safety and Health, USA) (84 CFR (Code of Federal Regulations) 11 [48]), or P2, P3, FFP2 and FFP3 according to the European standard EN143 [49] and EN149 [50].

The actual performance of respirators in the workplace is controlled by both filter performance and face-seal leakage, which depends on the with/without fit test, the selection of the size of the respirators, and education in the use of the respirator. It is not easy to define the face-seal leakage, but the total inward leakage (TIL) test of respirators, which includes leakage through the face seal between the respirator and a human subject or a mannequin, is a way to evaluate the performance.

The performance of the respirators depended on the size of aerosol particles. The worst performance was observed in the nanosize most penetrating particle size (MPPS). Eleven papers contained 13 cases that enabled MPPS calculation, which reported on the filtration efficiency of respirators, which did not include face seal leak (Black in Fig. 3) or total inward leakage (TIL) of the respirators (Gray in Fig. 3) [22-32]. The FFR using an electrostatic filter showed 30 to $70 \mathrm{~nm}$ of MPPS. This information should be noted as a caution on the mitigation of nanoparticle aerosols. The current official certification programs of particulate filters (84 CFR 11, EN 143, and EN 149) do not focus on nanoparticle aerosols [30].

In 14 papers we found 24 cases to obtain the $\mathrm{PF}_{\text {res }}$ of FFR and EHR respirators [22, 23, 25, 27-32, 34, 3740]. Based on the scores of the risk of bias in Table 2, we excluded 5 papers because of low scores [24, 26, $33,35,36]$. The $\mathrm{PF}_{\text {res }}$ were obtained from the data on the filtration efficiency of the respirators, which did not include face seal leak (Black in Fig. 4), and on the TIL of the respirators, which included leakage through the face seal (Gray in Fig. 4). Figure 4 shows the range of PFs obtained from the papers.

The values of $\mathrm{PF}_{\text {res }}$ of the $\mathrm{N} 95$ or equivalent grade FFRs were around 10. Higher grade masks, such as $\mathrm{P} 100$, had a much higher $\mathrm{PF}_{\text {res}}$, which may be acceptable from a hygienic point of view. The $\mathrm{PF}_{\text {res }}$ of cloth masks 
Table 3. List of engineering control techniques and estimated $\mathbf{P F}_{\text {eng }}$

\begin{tabular}{|c|c|c|c|c|}
\hline Ref no. & nanomaterials & instruments & research target & PF eng \\
\hline 7 & $\begin{array}{l}\mathrm{NaCl}, \mathrm{SF}_{6} \\
\text { nanoalumina }\end{array}$ & FMPS CPC & Commercial nano fume hood & No leak \\
\hline \multirow[t]{3}{*}{8} & Nanographene & DustTrak, FMPS & Process ventilation and process changes & 3.9 \\
\hline & Nanographene & DustTrak, FMPS & Downflow clean room with ventilated enclosure hood & No leak \\
\hline & Nanographene & DustTrak, FMPS & Reactor cabinet & No leak \\
\hline \multirow[t]{2}{*}{10} & MWCNT & $\mathrm{CPC}, \mathrm{OPC}$ & Custom made LEV & 0.125 \\
\hline & MWCNT & $\mathrm{CPC}, \mathrm{OPC}$ & BSC & 14.3 \\
\hline 11 & $\begin{array}{l}\text { Metal and metal } \\
\text { oxides, }(\mathrm{Ag}, \mathrm{Cu} \text {, } \\
\mathrm{Co}, \mathrm{Ni}, \mathrm{Fe}, \mathrm{Mn})\end{array}$ & $\begin{array}{l}\text { Filter sampling, } \\
\text { OPC, CPC }\end{array}$ & A portable HEPA filtered flanged LEV system & $\begin{array}{l}15.2(\mathrm{Cu}), 6.1(\mathrm{Ni}) \\
10.5(\mathrm{Fe}), 4.1(\mathrm{Mn})\end{array}$ \\
\hline 12 & Room aerosols & SMPS, ELPI, OPC & $\begin{array}{l}\text { Displacement ventilation by contaminated warm air } \\
\text { and cool supplied air }\end{array}$ & 10 or more \\
\hline \multirow[t]{2}{*}{14} & $\begin{array}{l}\text { Nanoscale } \\
\text { metal catalytic } \\
\text { materials, Mn, } \\
\text { Ag and Co }\end{array}$ & Filter sampling & A portable HEPA filtered flanged LEV system & $\begin{array}{l}24(\mathrm{Mn}), 3.9(\mathrm{Ag}) \\
17.3(\mathrm{Co})\end{array}$ \\
\hline & $\begin{array}{l}\text { Nanoscale } \\
\text { metal catalytic } \\
\text { materials, Mn, } \\
\text { Ag and Co }\end{array}$ & $\mathrm{CPC}, \mathrm{OPC}$ & A portable HEPA filtered flanged LEV system & 25 (mean of 3 cases) \\
\hline \multirow[t]{2}{*}{16} & $\begin{array}{l}\text { Nanoalumina, } \\
\text { Nanosilver }\end{array}$ & FMPS & Conventional hood: Transferring $100 \mathrm{~g}$ & $\begin{array}{l}4.2 \text { (Transfer), } \\
4.2 \text { (Pour) }\end{array}$ \\
\hline & $\begin{array}{l}\text { Nanoalumina, } \\
\text { Nanosilver }\end{array}$ & FMPS & By-pass hood: Transferring 100g & $\begin{array}{l}1.06 \text { (Transfer), } \\
1.53 \text { (Pour) }\end{array}$ \\
\hline \multirow[t]{3}{*}{17} & CNT & FMPS, APS & Enclosure for furnace & 10 \\
\hline & CNT & FMPS, APS & $\mathrm{BSC}$ w/wo recirculated air through HEPA filter & $\begin{array}{l}\text { No leak (fan on), } \\
3.2 \text { (fan off) }\end{array}$ \\
\hline & CNT & FMPS, APS & Canopy hood at cutting of nanocomposite sample & $\begin{array}{l}0.83 \text { by FMPS, } \\
0.81 \text { by APS }\end{array}$ \\
\hline \multirow[t]{2}{*}{18} & $\mathrm{TiO}_{2}$ synthesis & CPC, SMPS & Laboratory fume hoods, door open & 55 \\
\hline & $\mathrm{TiO}_{2}$ synthesis & CPC, SMPS & Laboratory fume hoods, door close & No leak \\
\hline \multirow[t]{2}{*}{19} & Welding fume & SMPS & Conventional booth & 2.7 \\
\hline & Welding fume & SMPS & Modified booth ventilation system & 2200 \\
\hline 21 & MWCNT & STEM & Ventialtion fan and segregation of source & No leak \\
\hline
\end{tabular}

$\left(\mathrm{PF}_{\text {eng }}=\mathrm{C}_{\mathrm{w} / \mathrm{o}} / \mathrm{C}_{\mathrm{w}}\right.$; concentrations without and with mitigation techniques), APS: Aerosol particle sizer, LEV: local exhaust ventilation, DustTrak: Aerosol photometer, BSC: Biosafety cabinet, FMPS: Fast Mobility Particle Sizer, SMPS: Scanning Mobility Particle Sizer, MWCNT: Multi-walled carbon nanotubes, CPC: Condensation particle counter, CNT: Carbon nanotube, ELPI: Electrical Low Pressure Impactor, OPC: Optical particle counter, STEM: Scanning transmission electron microscope

was very low. Cloth masks are useless in protecting workers handling nanomaterials. There was one paper on a loose-fitting powered air purifying respirator in which the PFs were measured in 3 human subjects [34], where the values of PFs were over 1.1 million, but those were not included in Fig. 4 because it was an outlier. We anticipate further studies on powered air purifying respirators for the handling of MNMs.

All the studies were observational and all were carried out in the laboratory and not under field conditions. The results across studies were inconsistent. Therefore we downgraded the evidence by one level to very low quality evidence for the effectiveness of respiratory protection. 


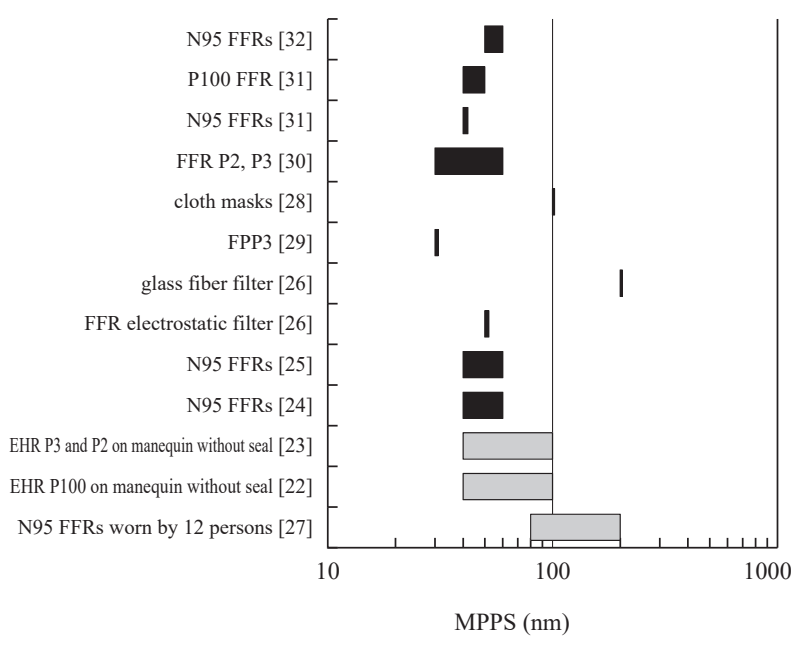

Fig. 3. Most penetrating particle size (MPPS) of studied respirators. Box shows the range of MPPS. Black boxes do not include face seal leak, and Gray boxes are total inward leakage (TIL) of respirator, which included leakage through face seal. Numbers in the brackets are reference number. FFR: filtering facepiece respirator or disposable type respirator. EHR: elastomeric half mask. N95, P100, P2 and P3 mean grades of respirator filters.

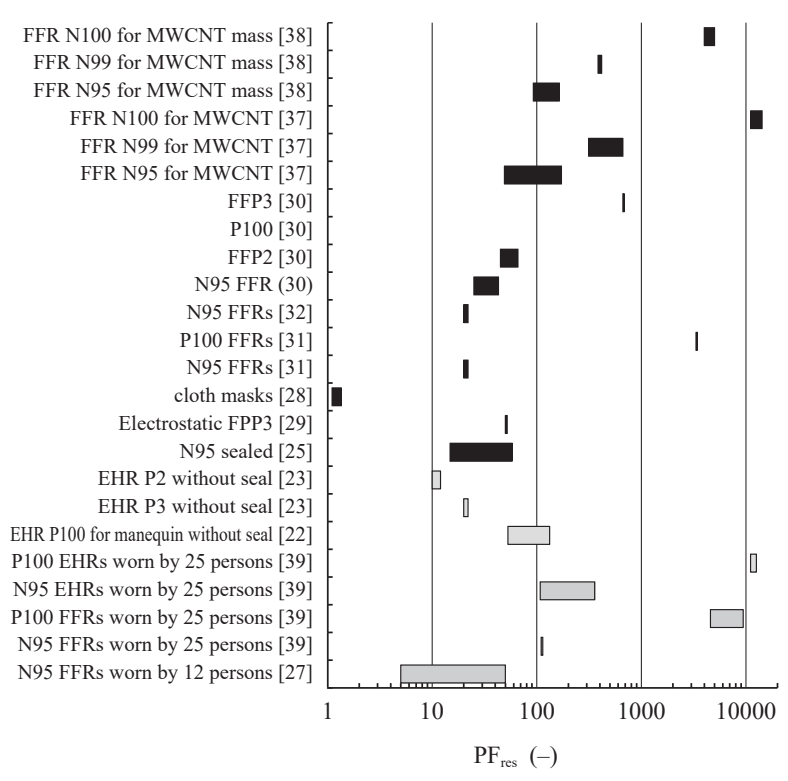

Fig. 4. Protection Factor of Respirators $\left(\mathrm{PF}_{\text {res }}\right)$. Black boxes do not include face seal leak, and gray boxes are total inward leakage (TIL) of respirators, which included leakage through face seal. Numbers in the brackets are reference number. FFR: filtering facepiece respirator or disposable type respirator. EHR: elastomeric half mask. MWCNT: Multi-walled carbon nanotubes. N95, N99, P100, P2, P3, FFP2 and FFP3 mean filtration performances of the respirator filters [48-50].

\section{Discussion}

We found 41 papers that indicated the effectiveness of engineering controls and respirators. For ventilation we found that local ventilation can achieve a protection factor of 10 to 20 but also that a canopy hood can even increase exposure. This is due to the face velocity and therefore a velocity of 0.4 to $0.6 \mathrm{~m} / \mathrm{s}$ is recommended. Only enclosure or segregation yield very good protection factors above 100 and should be used when exposure levels are high. For MNMs in powder form, good practices for ordinary powder handling processes are probably also effective in risk mitigation.

Automated packaging yielded only modest protection factors in a study of exposure to carbon nanotubes $\left(\mathrm{PF}_{\text {eng }}=4.9\right.$ to 8.2$)$, and in another study of nanoTiO exposure there was still a potential exposure risk when workers opened the packing closure and poured the material into a silo. MNMs have much more dustiness than submicron-size materials of the same chemical composition and therefore preventive measures should be much stricter for MNMs.

The PFs of N95 or equivalent grade FFRs were around 10. Higher grade respirators such as P100 had a much higher PF against nanoparticle aerosols. Cloth masks should not be used for workers handling MNMs. One study evaluated a powered air purifying respirator and found an extremely high protection factor. We anticipate more studies on powered air purifying respirators to MNMs in future.

A strength of this review is that we found that state of the art measurement instruments were used in the papers we reviewed. The aerosol concentrations were measured for both mass-based and count-based concentrations. For example, the scanning mobility particle sizer (SMPS) and the condensation particle counter (CPC) provide count-based concentration, while the gravimetric method using filter sampling provides mass-based concentration. The $\mathrm{PF}_{\text {eng }}$ was based on both number concentrations and mass concentrations. We did not find a clear difference between the PFs in the two concentrations.

The rating of the evidence of the reviewed papers started as low quality because all the studies were nonrandomized and non-controlled. Publication bias can be expected but could not be assessed due to lack of data. 


\section{Limitations}

Because the papers reviewed did not cover all the categories by Fransman et al [6], further studies are needed. More studies are needed on the effectiveness of risk mitigation by LEVs or fume cupboards and how face velocity and the workers' movements influence the outcomes.

Reports on the effectiveness of risk mitigation in automated processes were rare but would be important for workers' health, so further studies are needed in this area, too. Also, there was no paper on the control techniques for dustiness of MNMs, such as any additives.

In this review, the PFs of the respirators were based on concentrations of size-specific nanoparticle aerosols, but most of the test aerosols were sodium chloride aerosols or smoke and not real MNMs. Most reports on the respirators were limited to dust respirators, with the majority of the studies focusing on the filter performance without face seal leakage. In the same way as in ordinary respirator use, the face-seal leakage of respirators should be tested for workers handling any MNMs.

\section{Conclusion}

This review shows that there is great variation in the effectiveness of engineering controls and respiratory protection in reducing exposure to MNMs. We suggest that controls should be chosen that have a protection factor that will bring workers' exposure to MNMs below the proposed occupational exposure limits. In case of absence of such exposure limits and in absence of reliable toxicological information, the most protective controls should be used.

\section{Conflict of Interest}

The authors have no conflicts of interest.

\section{Acknowledgements}

The authors deeply appreciate Dr. E. Kortum, Prof. D. Brouwer and members of the WHO guideline development group for their assistance in the review.

\section{References}

1. ISO/TS 80004-2:2015 Nanotechnologies-VocabularyPart 2: Nano-objects

2. Debia M, Bakhiyi B, Ostiguy C, Verbeek JH, Brouwer DH \& Murashov V (2016): Systematic review of reported exposure to engineered nanomaterials. Ann Occup Hyg 60: 916-935

3. Mihalache R, Verbeek J, Graczyk H, Murashov V \& van Broekhuizen P (2017): Occupational exposure limits for manufactured nanomaterials, a systematic review. Nanotoxicology 11: 7-19

4. Morgan RL, Thayer KA, Bero L et al (2016): GRADE: Assessing the quality of evidence in environmental and occupational health. Environ Int 92-93: 611-616

5. Verbeek J, Ruotsalainen J \& Hoving JL (2012): Synthesizing study results in a systematic review. Scand J Work Environ Health 38: 282-290

6. Fransman W, Schinkel J, Meijstert T, Van Hemmen JJ, Tielemans E \& Goede H (2008): Development and evaluation of an exposure control efficacy library (ECEL). Ann Occup Hyg 52: 567-575

7. Dunn KH, Tsai SJ, Woskie SR, Bennett JS, Garcia A \& Ellenbecker MJ (2014): Evaluation of leakage from fume hoods using tracer gas, tracer nanoparticles and nanopowder handling test methodologies. J Occup Environ Hyg 11: D164-D173

8. Heitbrink WA, Lo LM \& Dunn KH (2015): Exposure controls for nanomaterials at three manufacturing sites. J Occup Environ Hyg 12: 16-28

9. Lee JH, Sohn EK, Ahn JS, Ahn K, Kim KS, Lee JH, Lee TM \& Yu IJ (2013): Exposure assessment of workers in printed electronics workplace. Inhal Toxicol 25: 426-434

10. Cena LG \& Peters TM (2011): Characterization and control of airborne particles emitted during production of epoxy/carbon nanotube nanocomposites. J Occup Environ Hyg 8: 86-92

11. Methner MM (2010): Effectiveness of a custom-fitted flange and local exhaust ventilation (LEV) system in controlling the release of nanoscale metal oxide particulates during reactor cleanout operations. Int J Occup Environ Health 16: 475-487

12. Hämeri K, Lähde T, Hussein T, Koivisto J \& Savolainen K (2009): Facing the key workplace challenge: assessing and preventing exposure to nanoparticles at source. 
Inhal Toxicol 21 Suppl 1: 17-24

13. Conti JA, Killpack K, Gerritzen G, Huang L, Mircheva M, Delmas M, Harthorn BH, Appelbaum RP \& Holden PA (2008): Health and safety practices in the nanomaterials workplace: results from an international survey. Environ Sci Technol 42: 3155-3162

14. Methner MM (2008): Engineering case reports. Effectiveness of local exhaust ventilation (LEV) in controlling engineered nanomaterial emissions during reactor cleanout operations. J Occup Environ Hyg 5: D63-D69

15. Tsai SJ, Huang RF \& Ellenbecker MJ (2010): Airborne nanoparticle exposures while using constant-flow, constant-velocity, and air-curtain-isolated fume hoods. Ann Occup Hyg 54: 78-87

16. Tsai SJ, Ada E, Isaacs JA \& Ellenbecker MJ (2009): Airborne nanoparticle exposures associated with the manual handling of nanoalumina and nanosilver in fume hoods. J Nanopart Res 11: 147-161

17. Lo LM, Tsai SJ, Dunn KH, Hammond D, Marlow D, Topmiller J \& Ellenbecker MJ (2015): Performance of particulate containment at nanotechnology workplaces. J Nanopart Res 17: 435

18. Sahu M \& Biswas P (2010): Size distributions of aerosols in an indoor environment with engineered nanoparticle synthesis reactors operating under different scenarios. J Nanopart Res 12: 1055-1064

19. Lee MH, McClellan WJ, Candela J, Andrews D \& Biswas P (2007): Reduction of nanoparticle exposure to welding aerosols by modification of the ventilation system in a workplace. J Nanopart Res 9: 127-136

20. Heitbrink WA \& Lo LM (2015): Effect of carbon nanotubes upon emissions from cutting and sanding carbon fiber-epoxy composites. J Nanopart Res 17: 335

21. Han JH, Lee EJ, Lee JH, So KP, Lee YH, Bae GN, Lee SB, Ji JH, Cho MH \& Yu IJ (2008): Monitoring multiwalled carbon nanotube exposure in carbon nanotube research facility. Inhal Toxicol 20: 741-749

22. He X, Grinshpun SA, Reponen T, McKay R, Bergman MS \& Zhuang Z (2014): Effects of breathing frequency and flow rate on the total inward leakage of an elastomeric half-mask donned on an advanced manikin headform. Ann Occup Hyg 58: 182-194

23. Brochot C, Michielsen N, Chazelet S \& Thomas D (2012): Measurement of protection factor of respiratory protective devices toward nanoparticles. Ann Occup Hyg 56: 595-605
24. Rengasamy S, Eimer BC \& Shaffer RE (2012): Evaluation of the performance of the N95-companion: effects of filter penetration and comparison with other aerosol instruments. J Occup Environ Hyg 9: 417-426

25. Rengasamy S \& Eimer BC (2012): Nanoparticle penetration through filter media and leakage through face seal interface of N95 filtering facepiece respirators. Ann Occup Hyg 56: 568-580

26. Rengasamy S \& Eimer BC (2012): Nanoparticle filtration performance of NIOSH-certified particulate airpurifying filtering facepiece respirators: evaluation by light scattering photometric and particle number-based test methods. J Occup Environ Hyg 9: 99-109

27. Reponen T, Lee SA, Grinshpun SA, Johnson E \& McKay $R$ (2011): Effect of fit testing on the protection offered by N95 filtering facepiece respirators against fine particles in a laboratory setting. Ann Occup Hyg 55: 264-271

28. Rengasamy S, Eimer B \& Shaffer RE (2010): Simple respiratory protection-evaluation of the filtration performance of cloth masks and common fabric materials against 20-1000 nm size particles. Ann Occup Hyg 54: 789-798

29. Golanski L, Guiot A, Rouillon F, Pocachard J \& Tardif F (2009): Experimental evaluation of personal protection devices against graphite nanoaerosols: fibrous filter media, masks, protective clothing, and gloves. Hum Exp Toxicol 28: 353-359

30. Rengasamy S, Eimer BC \& Shaffer RE (2009): Comparison of nanoparticle filtration performance of NIOSHapproved and CE-marked particulate filtering facepiece respirators. Ann Occup Hyg 53: 117-128

31. Rengasamy S, King WP, Eimer BC \& Shaffer RE (2008): Filtration performance of NIOSH-approved N95 and P100 filtering facepiece respirators against 4 to 30 nanometer-size nanoparticles. J Occup Environ Hyg 5: 556-564

32. Balazy A, Toivola M, Reponen T, Podgórski A, Zimmer A \& Grinshpun SA (2006): Manikin-based performance evaluation of N95 filtering-facepiece respirators challenged with nanoparticles. Ann Occup Hyg 50: 259-269

33. Li Y, Wong T, Chung J, Guo YP, Hu JY, Guan YT, Yao L, Song QW \& Newton E (2006): In vivo protective performance of N95 respirator and surgical facemask. Am J Ind Med 49: 1056-1065

34. Koivisto AJ, Aromaa M, Koponen IK, Fransman W, Jensen KA, Mäkelä JM \& Hämeri KJ (2015): Work- 
place performance of a loose-fitting powered air purifying respirator during nanoparticle synthesis. J Nanopart Res 17: 177

35. Tsai SJ (2015): Contamination and release of nanomaterials associated with the use of personal protective clothing. Ann Occup Hyg 59: 491-503

36. Rengasamy S \& Eimer BC (2011): Total Inward leakage of nanoparticles through filtering facepiece respirators. Ann Occup Hyg 55: 253-263

37. Vo E \& Zhuang Z (2013): Development of a new test system to determine penetration of multi-walled carbon nanotubes through filtering facepiece respirators. J Aerosol Sci 61: 50-59

38. Vo E, Zhuang Z, Birch E, Zhao Q, Horvatin M \& Liu Y (2014): Measurement of mass-based carbon nanotube penetration through filtering facepiece respirator filtering media. Ann Occup Hyg 58: 646-656

39. Vo E, Zhuang Z, Horvatin M, Liu Y, He X \& Rengasamy S (2015): Respirator performance against nanoparticles under simulated workplace activities. Ann Occup Hyg 59: $1012-1021$

40. He X, Vo E, Horvatin M, Liu Y, Bergman M \& Zhuang Z (2015): Comparison of simulated workplace protection factors offered by N95 and P100 filtering facepiece and elastomeric half-mask respirators against particles of 10 to $400 \mathrm{~nm}$. J Nanotechnol Mater Sci 2(2): 1-6

41. Koivisto AJ, Lyyränen J, Auvinen A, Vanhala E, Hämeri K, Tuomi T \& Jokiniemi J (2012): Industrial worker exposure to airborne particles during the packing of pigment and nanoscale titanium dioxide. Inhal Toxicol 24: 839-849

42. Takaya M, Serita F, Ono-Ogasawara M, Shinohara Y, Saito H \& Koda S (2010): Airborne particles in a multiwall carbon nanotube production plant: observation of particle emission and personal exposure 1: Measurement in the packing process. Sangyo Eiseigaku Zasshi
52: 182-188 (in Japanese)

43. Evans DE, Turkevich LA, Roettgers CT, Deye GJ \& Baron PA (2013): Dustiness of fine and nanoscale powders. Ann Occup Hyg 57: 261-277

44. O’Shaughnessy PT, Kang M \& Ellickson D (2012): A novel device for measuring respirable dustiness using lowmass powder samples. J Occup Environ Hyg 9: 129-139

45. Lee JH, Kuk WK, Kwon M, Lee JH, Lee KS \& Yu IJ (2013): Evaluation of information in nanomaterial safety data sheets and development of international standard for guidance on preparation of nanomaterial safety data sheets. Nanotoxicology 7: 338-345

46. Ma-Hock L, Treumann S, Strauss V, Brill S, Luizi F, Mertler M, Wiench K, Gamer AO, van Ravenzwaay B \& Landsiedel R (2009): Inhalation toxicity of multiwall carbon nanotubes in rats exposed for 3 months. Toxicol Sci 112: 468-481

47. Schneider T \& Jensen KA (2008): Combined singledrop and rotating drum dustiness test of fine to nanosize powders using a small drum. Ann Occup Hyg 52: 23-34

48. National Institute for Occupational Safety and Health (NIOSH) (1995): 42 CFR part 84 respiratory protective devices; final rules and notice. Federal register 60: 110. NIOSH, OH pp 30336-30398: https://www.gpo. gov/fdsys/pkg/FR-1995-06-08/pdf/95-13287.pdf

49. European Standard (2000): Respiratory protective devices - particle filters - requirements, testing, marking. European Standard EN 143: https://shop.bsigroup.com/ ProductDetail/?pid=000000000030144411

50. European Standard (2001): Respiratory protective devices - filtering half masks to protect against particles - requirements, testing, marking. European Standard EN 149: https://shop.bsigroup.com/ProductDetail/?pid $=000000000030178264$ 
工業用ナノマテリアルの製造と取扱いで用いられる個別のリスク低減対策の効果：システマティック レビュー

明星 敏彦 ${ }^{1}$, 永田 智久 ${ }^{2}$, ジョス バビーク 3

1 産業医科大学 産業生態科学研究所 労働衛生工学

2 産業医科大学 産業生態科学研究所 産業保健経営学

3フンランド労働衛生研究所

要旨：多くの工業用ナノマテリアルが産業製品の基本材料として開発され使用されており, それらは開発国 だけでなく開発途上国の労働者への健康リスクを持つ可能性がある. 工業用ナノマテリアルの曝露低減対策の効果 を証明する研究はほとんどないので, 我々は2000年から 2015年までに公表され特定された工業用ナノマテリアルの リスク低減対策の研究をシステマティックに調查した。ここでは, 状況に曝露低減対策を入れた場合と入れない場 合を比較し, 工業用ナノマテリアルの曝露を測定した研究を採用した。 これらの対策の効果を判定するために, 我々 は工業用ナノマテリアルの低減対策の効果の尺度として防護係数, 対策の有無による有害物濃度の比として定義さ れる文献を使用した。ここではPubMedの1,131レコードや他の文献リストから, 41 の文献を条件に合致したものと して抽出した。そして局所排気装置, 密閉化, プロセス自動化などの工学的対策や, 個人用保護具に分類した。密閉

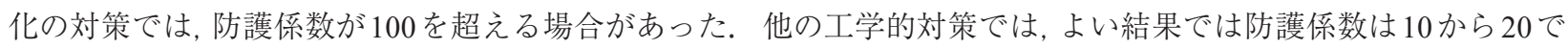
あったが, 多くの局所排気装置では 10 以下, 時に状況を悪くする場合もあった． N95や同等のグレードの使い捨て式 防じんマスクはナノサイズの試験エアロゾルに対して10程度の防護係数を持っていた．工学的対策は工業用ナノ マテリアルへの曝露を低減するが, 密閉化のシステムの方がより効果的であることに弱い証拠があると結論付けた. 呼吸用保護具は現場での研究が少ないため弱い証拠があると判定した。 工業用ナノマテリアルが職業曝露限界を超 える場合,または, その毒性情報がない場合に対策を決定するため上記の情報を使うことができる.

キーワード：工業用ナノマテリアル, システマティックレビュー, 工学的対策, 呼吸用保護具, プロセス自動化. 